\title{
Development of Relational Capability in Technology-based Companies in the Information and Communication Technology Sector
}

\author{
João Marcos Silva de Almeida, Priscila Rezendeda Costa
}

\begin{abstract}
Relational capacity is defined as the ability of companies to relate with other companies as well as their internal borders. One of these relationships is strategic alliances, which are basically agreements in which companies seek mutual cooperation or attempt to expand their resource base to address their needs. This process includes taking risks to achieve common goals. This article aims to describe the situation of two technology-based companies (TBCs) in the information and communication technology (ICT) sector and examine how they develop their relational front capacity in terms of the main existing theoretical concepts. One company is considered a leader in its field in Brazil. It was structured directly in the market without any support or development. The other was structured in an incubator run by one of the largest public universities in Brazil, with all possible resources for advancement. Therefore, there were significant differences in the development of their relational capabilities. The study was conducted through direct interviews for data collection and subsequent analysis and conclusion.
\end{abstract}

Keywords: Technology-Based Company; Information and Communication Technology; Relational Capability; Strategic Alliance.

Abbreviations: Technology-Based Company (TBC); Information and Communication Technology (ICT).

\section{INTRODUCTION}

Companies are currently facing intense environment changes in terms of technology and forces within the market itself.

In an attempt to overcome this dynamism, many companies are using innovation to gain a competitive advantage not only remain in the market but also to prevail over their competitors. According to [1], discussing evolution and development as a process of creative destruction in which innovations lead to the destruction of the current practice, innovations tend to replace previous innovations. Thus, the capacity to innovate becomes a differential and the factor responsible for the success or failure of an organization.

As companies often do not internally have all the expertise and/or resources to achieve these goals, they seek new skills to complement their needs or disabilities externally, and it is through relational capability, i.e., the ability of firms to enter into strategic partnerships and alliances, that they are able to expand their resources and acquire new skills. To [2], strategic alliances are agreements in which two or more partners share the commitment to conduct an activity together, sharing their skills and resources and coordinating activities.

Given this context, and to delve more deeply into this issue, we sought to identify the relational capacity development stage in two technology-based companies (TBCs) in the information and communication technology (ICT) sector with different profiles, one structured within the market areas and the other structured in an incubator. For this purpose, descriptive qualitative research was conducted.

The relevance of this research is justified by its contribution to understanding and leveraging the development of relational capacity in TBCs.

\section{TheOretical FrameWORK}

\subsection{Technology-Based Companies (TBC)}

Technology-based companies aid the development of a nation through important socio-economic benefits such as support for industrialization, technological development and creating new jobs. They 
have different characteristics from traditional companies, as they operate in dynamic segments where innovation is a constant part of their activities. According to[3], the activities of TBCs require the generation of intensive technologies to create new products, processes and services.

In Brazil, a TBC is an "enterprise whose main activity focuses on developing new products and processes based on a systematic application of scientific and technological knowledge and the use of pioneering and advanced techniques" [4].

\subsection{Information and Communication Technology Companies}

One of the major vectors of change in the competitive landscape is the continuous evolution of technology due to its widespread use, significantly affecting all human activities and increasing the degree of uncertainty and unpredictability of the future. Among the new technologies is Information Technology (IT), which has become an important competitive component for organizations [5].

Information technology covers a range of hardware products and software capable of collecting, storing, processing and accessing numbers and images, which are used to control equipment and work processes, and connect people, functions and offices within and between companies [6].

Unlike the data, the information is organized and has meaning [7]. Thus, developing skills and abilities in finding, processing and storing information has become a competitive advantage for companies, and advances in information technology have greatly contributed to this process.

The focus of information technology has changed so much that the term IT has come to be used as Information and Communication Technology (ICT). Within this universe, new ideas and innovations have begun to be built.

\subsection{Relational Capabilities}

In a strategic alliance, companies cooperate to satisfy their mutual needs and share risks to achieve common goals. A strategic alliance provides many more features than a single company could purchase or own [8].

As has been highlighted [2], strategic alliances are agreements in which two or more partners share the commitment to conduct an activity together, sharing their skills and resources and coordinating activities. [9] explain that the coordination of a partnership can be divided into two tasks: inter organizational coordination and coordination of the partnership portfolio. While the inter-organization refers to the coordination of individual partnerships [10], the partnership portfolio coordination deals with the integration of all strategic partnerships of an organization [11].

A contractual strategic alliance is a long-term relationship between independent firms that share complementary resources for joint activities, managed through formal contracts and coordination devices [12]. It can be argued, according to [13], that alliances are made between companies to work together in order to achieve certain strategic objectives.

Thus, alliances offer unique opportunities for a company to develop its strength with a broad set of partners who may be customers, suppliers, competitors, distributors, universities or other industries. Furthermore, the exchange of experiences will also result in the absorption of knowledge that can and should be used internally to improve administrative and organizational processes.

Therefore, the relational capacity construct is adopted as a dynamic capability of companies to develop their resource base through formal and intentional partnerships [14].

As this construct, according to [15], is founded by categories and models related to the dynamic capability to establish strategic partnerships, we can summarize the central categories and authors, as illustrated in Table 1.

Table1. Categories underlying the relational capacity construct

\begin{tabular}{|c|c|c|}
\hline Description the construct relational capacity \\
\hline $\begin{array}{c}\text { Selection of } \\
\text { external partners } \\
\text { for innovation }\end{array}$ & $\begin{array}{c}\text { Companies create major relational capabilities when technological opportunities are } \\
\text { highly complementary and with strategic partners. To this end, a strategic technology to } \\
\text { identify opportunities is needed, which also includes a continuous prospecting activity } \\
\text { and classification of new partners. Reputation, previous experience, needs and } \\
\text { opportunities of stakeholders play an important role in mate selection. Furthermore, } \\
\text { technological and / or scientific complementarity between partners is required to offer } \\
\text { incentives for mutual cooperation }\end{array}$ \\
\hline
\end{tabular}




\begin{tabular}{|c|c|}
\hline $\begin{array}{c}\text { Kind of } \\
\text { knowledge } \\
\text { sought in } \\
\text { external partners }\end{array}$ & $\begin{array}{c}\text { Companies create and strengthen relational capacity when establishing priorities for } \\
\text { acquiring the type of knowledge that they seek, and the knowledge gained will help to fill } \\
\text { gaps and compensate for the resources not available within the company. }\end{array}$ \\
\hline $\begin{array}{c}\text { Nature of } \\
\text { innovation } \\
\text { developed in } \\
\text { partnership with } \\
\text { external actors }\end{array}$ & $\begin{array}{c}\text { Companies seek a partnership to meet their needs for product improvement (incremental } \\
\text { innovation) or the introduction of an entirely new product (radical innovation). }\end{array}$ \\
\hline $\begin{array}{c}\text { Formalization of } \\
\text { partnerships for } \\
\text { innovation }\end{array}$ & $\begin{array}{c}\text { To strengthen and provide transparency and credibility in partnerships or alliances, it is } \\
\text { crucial for companies to formalize these through some kind of contract or agreement of } \\
\text { key responsibilities, desired goals and deliverables. }\end{array}$ \\
\hline $\begin{array}{c}\text { Synchronization } \\
\text { of decisions and } \\
\text { innovation } \\
\text { activities with } \\
\text { external partners }\end{array}$ & $\begin{array}{c}\text { In an effective partnership, it is crucial for companies to have internal processes to ensure } \\
\text { that all parties have the right information with clear and defined objectives. }\end{array}$ \\
\hline $\begin{array}{c}\text { Resolution of } \\
\text { conflicts of } \\
\text { interests in } \\
\text { partnerships for } \\
\text { innovation }\end{array}$ & $\begin{array}{c}\text { In a partnership or alliance, it is important for the role of each company to be well } \\
\text { defined through processes, targets and deadlines to avoid possible conflicts or even } \\
\text { disputes of interest that may weaken or destroy the partnership. }\end{array}$ \\
\hline $\begin{array}{c}\text { Evaluation of } \\
\text { business model } \\
\text { based on external } \\
\text { partnerships for } \\
\text { innovation }\end{array}$ & $\begin{array}{c}\text { Thternalized by the company, as well as the resulting learning curve. Thus, analytical } \\
\text { tools are fundamental when it comes to highlighting the results. }\end{array}$ \\
\hline
\end{tabular}

Source: [9]; [14]; [15]; [16]; [17].

\section{RESEARCH METHOD}

The research is qualitative and descriptive in nature. [18] argues that qualitative research is characterized as an attempt to gain an in-depth understanding of the meanings and situational characteristics presented by the respondent, rather than producing quantitative measures of behavioral characteristics.

The construction of case study is a research strategy that involves the use of one or more cases to create theoretical constructs and/or propositions using empirical evidence from corresponding studies [19]. [20] claims that intensive study in some cases allows deep, thorough and comparative evaluation of one or a few objects. This does not mean seeking to generalize or create new business models or business. At this time, what is sought is the contribution that can be achieved by analyzing these two real cases in the light of the available literature to see whether there is some kind of convergence.

Digital Access and Sollis Innovation are the two cases that were studied.

Primary and secondary data were used. According to [21],primary data are collected for the specific purpose of a study, while secondary data have already been collected, tabulated, sorted and sometimes even analyzed elsewhere.

The data were collected in July and August of 2015, and the secondary on the companies were obtained from bibliographies and online. This enabled the mapping of their general characteristics, performance history, portfolios and key partners.

The primary data were collected through structured interviews, with a script as the information collection tool to ensure that the same question was asked in the same way to the interviewee. [20], explains that "the interview develops from a fixed list of questions, whose order and wording remains the same for all respondents." The interviews were conducted with the manager and lasted an average of 40 minutes. They were recorded and later transcribed.

To interpret the collected data, document analysis and content analysis were used. To[22], document analysis involves selecting, processing and interpreting existing information in documents, whether in print, audio or video. According to[23], content analysis is a technique to read and interpret the 
contents of an entire document class so that, when properly analyzed, we open the doors to knowledge of aspects and phenomena of social life that would otherwise be inaccessible.

\section{Results}

The following are reported excerpts of the transcript of the interviews and the information obtained from Digital Access and Sollis Innovation. Portrayals of the characterization of both companies will be presented.

\subsection{Diagnosis of DIGITAL ACCESS}

Digital Access is a Brazilian company and a pioneer in the service model, and process and document management technology. Its focus is on providing greater efficiency to the country's companies. With an annual average growth of $70 \%$, it is the only Brazilian company among the 25 fastest growing in the country in the last three years. It is used by large companies from different sectors. The technology service package consists of software, scanners and an internet portal to enable companies to scan and manage document processes in a simple and organized way.

After a visit to Google in California (USA), which is recognized for innovation and its people management policies, the owner remarked that it was possible to have a relaxed working environment that was also productive. This was a goal when the company was founded.

In 2002, Digital Access was born as a consulting firm for document scanning. In 2008, the business entered a new phase and now offers scanning services and document storage. Today, Digital Access is the next best technology company to work for in Brazil, behind Google and ahead of Microsoft.

The company currently has partnerships in areas such as product development and technology, as well as data storage companies or centers, as the volume of information is large and continues to grow. Its approximately 400 clients include TIM, Vivo, Bradesco, Citibank, Peugeot and BMW.

It is worth mentioning that Digital Access was elected the 8th fastest growing company in Brazil (Ranking Deloitte/Magazine SMEs) and the 3rd Best Company to Work for in IT and Telecom, by the Institute Great Place to Work. It has been an Endeavor company since 2001.

The company currently has 150 employees. In the last three years, approximately 12 new and established products have been launched, developed and/or improved by approximately 35 support processes.

The company reserves approximately $0.4 \%$ of its turnover for research and development, but no revenues are earmarked for research institutions or universities.

Digital Access allocates approximately $30 \%$ of its staff to engineering, research and development, and approximately 3\% hold a Master's Degree or Doctorate.

Regarding the relational capacity of the company, we adopted the following categories of analysis: 1) selection of foreign partners for innovation; 2) Type of knowledge sought in external partners; 3) Nature of innovation developed in partnership with external stakeholders; 4) Formation of partnerships for innovation; 5) Synchronization of decisions and innovation activities with external partners; 6) Resolution of conflicts of interests in partnerships for innovation; and 7) assessment of business model based on external partnerships for innovation.

In the Digital Access survey, the technological skills that lead to the future for the company and the selection of new partners for innovation are associated with the experience, contacts and business references of the founder and other managers. As reported by the respondent, the company implemented organizational innovations through the personal references and contacts of the founder and other managers with technology companies in Silicon Valley. It should also be stated that learning and subsequent implementation in Brazil of a new process called OCR (Optical Character Recognition) technology, today the base for the company's business, resulted from a visit to the holder of this technology. The company was based in Germany and was already a supplier of Digital Access, i.e., the partnership was established through previous contact between the founder, managers and an international supplier.

Regarding the criteria adopted for the selection of new partners, the company currently receives mentoring from Endeavor regarding initial indications and approaches between the parties, while these criteria are absent from the internal context. 
The interview was conducted with Mr. Eric Alberto (Director of Technology and Information Security).He said that external partners are selected in many different ways. There is a rule that depends on the type of innovation that the company is seeking at the time, and partners can range from a start-up to large enterprises. The company is connected to Endeavor, which functions as a kind of mentor and provides connections with a series of other companies in Brazil and abroad. When dilemmas arise, Endeavor's mentoring aids decision-making.

An example of innovation that warrants special attention was the technology for character recognition in digital documents. The interviewee reports, "I went to Germany to visit the company that owns this technology. I learned about it and brought this technology to Brazil. There is no formal agreement for these partnerships. We work with a high level of trust between companies. So far, we have not detected any cases of conflict and emphasize that this trust is established in the form of respect. Innovation is in the DNA of the company. No one was contracted for this type of function. We work collaboratively."

Table2. Company characterization: ACCESS DIGITAL

\begin{tabular}{|c|c|}
\hline Characterization of Companies & ACCESS DIGITAL \\
\hline 1. Number of employees & 150 \\
\hline $\begin{array}{l}\text { 2. Approximate number of technologically new or significantly improved products } \\
\text { developed in the last three years. }\end{array}$ & 12 \\
\hline $\begin{array}{l}\text { 3. Approximate number of technologically new or significantly improved } \\
\text { processes developed over the past three years. }\end{array}$ & 35 \\
\hline $\begin{array}{l}\text { 4. Approximate percentage (\%) of the company's revenues obtained through the } \\
\text { sale of products protected by patents or software registration, or in the process } \\
\text { of acquiring of these protections. }\end{array}$ & $\begin{array}{l}\text { No information } \\
\text { available }\end{array}$ \\
\hline $\begin{array}{l}\text { 5. Approximate percentage }(\%) \text { of the turnover of the company intended for } \\
\text { research activities and technological development. }\end{array}$ & $4 \%$ \\
\hline $\begin{array}{l}\text { 6. Approximate percentage }(\%) \text { of company revenue earmarked research } \\
\text { institutions or universities to develop research projects related to the } \\
\text { development and improvement of its products or processes. }\end{array}$ & $0 \%$ \\
\hline $\begin{array}{l}\text { 7. Approximate percentage }(\%) \text { of higher-level technical professionals engaged in } \\
\text { software development activities, engineering, research and technological } \\
\text { development. }\end{array}$ & $30 \%$ \\
\hline $\begin{array}{l}\text { 8. Approximate percentage }(\%) \text { of professors, doctors or similar levels of } \\
\text { professionals engaged in research activities and technological development }\end{array}$ & $3 \%$ \\
\hline
\end{tabular}

Source: Prepared by the authors

\subsection{Diagnosis of Sollis Innovation}

SOLLIS is a Brazilian company founded in 2010. It is located at the CIETEC (Center for Innovation, Entrepreneurship and Technology) as an incubated company. Since its foundation, it has developed software solutions for electronic prescription, facilitating interaction between doctors, patients and pharmacies, allowing these medical professionals, patients and healthcare facilities to exchange information electronically within a community of care across the country. Its entire operational structure is supported by a team of four people, including a financial executive and medical director. Among these people is Caio Ribeiro Gonçalves (Executive Marketing and Communication), the son of a founding partner, who welcomed us and gave us an interview.

In the past three years, 2 new products have been launched and four support processes have been designed, developed and improved.

The company designates approximately $20 \%$ of its turnover for research and development, but no revenues are reserved for research institutions or universities.

Approximately $98 \%$ of Sollis Innovation's staff are allocated to engineering and R\&D. Approximately 5\% are holders of Master's Degrees or Doctorates.

Regarding the relational capacity of the company, we adopted the same categories of analysis as we did for the previous company: 1) Selection of foreign partners for innovation; 2) Type of knowledge sought in the external partners; 3) Nature of innovation developed in partnership with external stakeholders; 4) Drawing up of partnerships for innovation; 5) Synchronization of decisions and 
innovation activities with external partners; 6) Resolution of conflicts of interest in partnerships for innovation; and 7) assessment of business model based on external partnerships for innovation.

According to Mr. Caio Ribeiro, the company's main partners include multinational companies such as FAPESP, and its main customers are doctors' surgeries and medical clinics, pharmacies and hospitals.

The company has several partners. Most, as mentioned, are multinational companies. The company seeks technology partners that are complementary to the business: "There is no formal contract. Usually, these partners provide a free license for three years for us to develop our projects. They believe this is sufficient time for the development of a new business. After that, there is a fee for license renewal, and in some cases, there is a prize. In other cases, there may be an online agreement signed between the companies."

An outstanding partnership was established with a multinational company that develops software and hardware for businesses rather than the end consumer. "We are developing a platform for working to improve the process of our services. In this specific case, we signed a pre-contract agreement, and after 120 days, when we judge that we have already sorted out all the details and everything works as expected, a contract will be signed with them that will give them the right to sell our solution on the market."

According to the respondent, the biggest problem, and one that often creates some kind of conflict, is time versus investment, because this type of business "needs time to develop, so it is essential to understand and work within our partner's profile. The upside is that although the company is small it usually works with major partners, meaning that we have a great vision."

Table3. Company characterization: Sollis Innovation

\begin{tabular}{|c|c|}
\hline Characterization of Companies & SOLLIS \\
\hline 1. Number of employees & 6 \\
\hline $\begin{array}{l}\text { 2. Approximate number of technologically new or significantly improved } \\
\text { products developed in the last three years. }\end{array}$ & 2 \\
\hline $\begin{array}{l}\text { 3. Approximate number of technologically new or significantly improved } \\
\text { processes developed over the past three years. }\end{array}$ & 4 \\
\hline $\begin{array}{l}\text { 4. Approximate percentage }(\%) \text { of the company's revenues obtained through } \\
\text { the sale of products protected by patents or software registration, or in the } \\
\text { process of acquiring these protections. }\end{array}$ & $5 \%$ \\
\hline $\begin{array}{l}\text { 5. Approximate percentage }(\%) \text { of the turnover of the company intended for } \\
\text { research activities and technological development. }\end{array}$ & $20 \%$ \\
\hline $\begin{array}{l}\text { 6. Approximate percentage (\%) of company revenue earmarked for research } \\
\text { institutions or universities, to develop research projects related to the } \\
\text { development and improvement of its products or processes. }\end{array}$ & $5 \%$ \\
\hline $\begin{array}{l}\text { 7. Approximate percentage }(\%) \text { of higher-level technical professionals } \\
\text { engaged in software development activities, engineering, research and } \\
\text { technological development. }\end{array}$ & $98 \%$ \\
\hline $\begin{array}{l}\text { 8. Approximate percentage (\%) of professors, doctors or similar levels of } \\
\text { professionals engaged in research activities and technological development }\end{array}$ & $5 \%$ \\
\hline
\end{tabular}

Source: Prepared by the authors

\section{Conclusions}

Through the data collection and analysis of the situation, we can see that the technology-based companies (TBCs) in question are young companies that continue to grow and mature in their respective areas of expertise, operational structures and presence in the marketplace.

Neither company is consistently mature regarding their strategies and procedures when forming strategic partnerships or alliances. This is demonstrated by the high degree of informality in their internal and external processes, including the prospection, selection and formalization of partnerships. This is not in keeping with the literature, with differences in the construct of relational capability, as companies develop greater relational skills when they find technological opportunities and highly complementary strategic partners [9] [17].

The search for new partners in both cases is conducted informally, and in the case of Digital Access through mentoring, with records of the procedures in this operation. Thus, with a diverging construct of relational capacity, it would be necessary to have a continuous activity of exploration and 
classification of new partners and strategic technology planning to identify opportunities [16]. Another point to consider is reputation, previous experience, needs and opportunities of stakeholders, who play an important role in mate selection [15] [24]. They were also considered important by the respondents, but there is a lack of records and procedures attesting to the verification and validation of these items.

The evidence available in this study through the profile and active follow-up of these companies is that the search for and selection of new partners will always be a normal activity within strategic planning. The interviews also show that these companies consider partnerships a key element for the development and acquisition of new resources to strengthen their competitive advantages.

No attempt was made in this study to generalize or create new business models or business. Rather, the article sought to contribute to the field by analyzing these two real cases of companies that were structured in different ways for the market. It can be ascertained that the analysis of the seven categories identified is no major differences were found in the relational capacity development stage considering the individual profiles of each company. Furthermore, despite the high degree of informality in their operations, the concept of capacity relational through partnerships or alliances permeate their organizational operations. The difference between the companies is that the incubated company suffers greater and stronger harassment from potential partners, while the company that is not incubated must seek potential partners in the market. A limitation of the study is that the survey was conducted in depth with only two companies. It would be interesting to include more companies to seek possible changes in these patterns.

\section{REFERENCES}

[1] Schumpeter, J. A. The theory of economic development: An inquiry into profits, capital, credit, interest, and the business cycle. Transaction publishers. (1934).

[2] Teece, D. J. Competition, cooperation, and innovation: Organizational arrangements for regimes of rapid technological progress. Journal of Economic Behavior \& Organization, 18(1), 1-25, (1992).

[3] Storey, D. J., Tether, B. S. New technology-based firms in the European Union: an introduction. Research Policy, 26(9), 933-946, (1998).

[4] ANPROTEC. National Association of Entities Advanced Technology Enterprises promoters. Dynamic glossary of terms on technopolis area, technology parks and business incubators. Brasilia: Anprotec (2002).

[5] Albano, C. S. Adoption of new information technologies: a study of problems and actions in Agricultural Cooperatives of Rio Grande do Sul. ANNUAL MEETING OF THE NATIONAL ASSOCIATION OF GRADUATE MANAGEMENT PROGRAMS. Campinas, São Paulo, (2001).

[6] Walton, R. Information technology: the use of IT by companies that obtain competitive advantage. São Paulo: Atlas.(1993).

[7] Davenport, T. H., Prusak, L. Working knowledge: How organizations manage what they know. Harvard Business Press. (1998).

[8] Lewis, J. D. Alianças estratégicas: estruturando e administrando parcerias para o aumento da lucratividade. Pioneira. (1992).

[9] Schilke, O., Goerzen, A. Alliance management capability: an investigation of the construct and its measurement. Journal of Management, 36(5), 1192-1219, (2010).

[10] Gulati, R., Nickerson, J. A. Inter organizational trust, governance choice, and exchange performance. Organization Science, 19(5), 688-708, (2008).

[11] Goerzen, A., Beamish, P. W. The effect of alliance network diversity on multinational enterprise performance. Strategic Management Journal, 26(4), 333-354, (2005).

[12] Gibbons, R., Henderson, R. Relational contracts and organization capabilities. Organization Science, 23(5), 1350-1364, (2012).

[13] Harrigan, K. R. Strategic alliances and partner asymmetries. Graduate School of Business, Columbia University. (1988). 
[14] Lorenzoni, G., Lipparini, A. The leveraging of interfirm relationships as a distinctive organizational capability: a longitudinal study. Strategic Management Journal, 20(4), 317-338, (1999).

[15] Helfat, C. E., Finkelstein, S., Mitchell, W., Peteraf, M. A., Singh, H., Teece, D. J., Winter, S. G. Dynamic capabilities. Understanding strategic change in organizations. (2007).

[16] Cohen, W. M., Levinthal, D. A. Absorptive capacity: a new perspective on learning and innovation. Administrative science quarterly, 128-152, (1990).

[17] Teece, D. J., Pisano, G., Shuen, A. Dynamic capabilities and strategic management. Strategic management journal, 18(7), 509-533, (1997).

[18] Richardson, R. J. Social Research: Methods and techniques. São Paulo: Atlas, 1999. Robbins, Stephen P. Administration: Changes and Perspectives. Sao Paulo: Saraiva, (2000).

[19] Yin, R. K. Qualitative research from start to finish. Guilford Press. (2010).

[20] Gil, A. C.. How to design research projects. Sao Paulo, 5, 61.(2002)

[21] MATTAR, F.N. Pesquisa de marketing: metodologia, planejamento. Vol. 1, $5^{\text {a }}$ ed. São Paulo: Atlas, (1999).

[22] Carmo, H., Ferreira, M. M. Research methodology guide for self-study. (1998).

[23] Olabuénaga, J. I. R., Ispizua, M. A. La descodificación de la vidacotidiana: Métodos de investigacióncualitativa. Bilbao: Universidade de Densto. La descodificación de la vidacotidiana: Métodos de investigación cualitativa. Bilbao: Universidade de Densto. (1989).

[24] Petruzzelli, A. M. The impact of technological relatedness, prior ties, and geographical distance on university-industry collaborations: A joint-patent analysis. Technovation, 31(7), 309-319, (2011). 